\title{
Multiscale patterns of habitat and space use by the pacarana Dinomys branickii: factors limiting its distribution and abundance
}

\author{
Carlos A. Saavedra-Rodríguez ${ }^{1,2, *}$, Gustavo H. Kattan ${ }^{3,4}$, Karin Osbahr ${ }^{5}$, \\ Juan Guillermo Hoyos ${ }^{4}$
}

\author{
${ }^{1}$ Wildlife Conservation Society Colombia Program, Carrera 25 No. 4-39, Cali, Colombia \\ ${ }^{2}$ Grupo de Investigación en Ecología Animal, Departamento de Biología, Universidad del Valle, A. A. 25360, Cali, Colombia \\ ${ }^{3}$ Departamento de Ciencias Naturales y Matemáticas, Pontificia Universidad Javeriana, Calle 18 No. 118-250, Cali, Colombia \\ ${ }^{4}$ Fundación EcoAndina, Carrera 2 A Oeste No. 12-111, Cali, Colombia \\ ${ }^{5}$ Unidad de Investigación en Fauna Silvestre, Universidad de Ciencias Aplicadas y Ambientales, Calle 222 No. 55-37, Bogotá, \\ Colombia
}

\begin{abstract}
The factors that influence habitat and space use by animals, and therefore their distribution and abundance, vary with spatial scale. The pacarana Dinomys branickii is a large rodent of the tropical Andes threatened by illegal hunting and habitat loss. We identified variables related to pacarana habitat use at 4 spatial scales in the Colombian Andes: landscape $\left(3.14 \mathrm{~km}^{2}\right.$ circles), forest patch, foraging area, and den. At the landscape scale, pacaranas used areas with 20 to $95 \%$ forest cover that were not different from randomly sampled sites. At the forest fragment scale, used patches (mean $=12 \mathrm{ha}$ ) were larger than unused patches, but independent of distance to continuous forest. At the foraging area scale, habitat use was related to the presence of rocky caves used as dens and was unrelated to forest structure. At the den scale, pacaranas used deep caves $\left(>4 \mathrm{~m}\right.$ ) in sloping rocky outcrops with $>40 \%$ exposed rock (in $100 \mathrm{~m}^{2}$ patches). Pacarana groups ( 4 to 5 individuals) had a mean home range of 2.45 ha around caves. We estimated a population density of 9.9 and 5.5 groups $\mathrm{km}^{-2}$ based on sign clusters (footprints, latrines, and foraging areas) and dens, respectively. Pacaranas fed on a variety of plant families found in primary and secondary forest and disturbed areas near streams. Our results indicate that pacaranas can survive in forest fragments, and the main factor limiting their distribution and abundance is the availability of adequate dens. Conservation of pacarana populations in rural landscapes may be helped by protecting a network of forest patches connected by riparian vegetation, but these populations would be vulnerable to illegal hunting.
\end{abstract}

KEY WORDS: Den $\cdot$ Forest fragmentation $\cdot$ Habitat use $\cdot$ Home range $\cdot$ Population density Resale or republication not permitted without written consent of the publisher

\section{INTRODUCTION}

Understanding patterns of habitat and space use is essential for the conservation of populations of threatened animals (Johnson et al. 2004). The habitat features that animals require and the factors that limit their distribution vary at different spatial scales (Ciarniello et al. 2007). At large scales, the presence of populations is determined by factors such as geomorphology, topography, and habitat configuration. At small scales, resource availability is one of the major factors influencing the distribution and ranging patterns of individual animals (Johnson 1980). 
Multiscale studies provide critical information for supporting conservation actions, because they allow the identification of scale-specific variables that limit the persistence of populations, and they support the development of effective management options (Boyd et al. 2008). For example, the occurrence of small mammals and birds is in some cases better predicted by landscape than by microhabitat variables (Saab 1999, Coppeto et al. 2006). However, species responses may differ within a taxonomic group. The occurrence of some species of dasyurid marsupials in Australia is better predicted at coarse spatial scales, but other species respond to microhabitat variables at fine scales (Haythornthwaite \& Dickman 2006). Some animals respond to the presence or abundance of specific resources at local scales. For instance, the presence of brown treecreepers Climacteris rufa in Australia is related to the density of tree holes (i.e. nest sites; Luck 2002). If an animal is limited by the availability of a particular resource at a local scale, then investing in increasing the amount of habitat cover without making sure that the resource is present would be ineffective.

The conservation of animal populations also requires knowledge of animals' space needs and general habits, such as foraging behavior and social structure (Swihart et al. 1988), as these factors determine the area requirements of individuals (home range sizes) and populations (population density and size). In particular, animals that roost in burrows must return to the burrow every day, and therefore are constrained in their foraging areas and movement patterns (central place foragers; Swihart et al. 1988). Their spatial distribution and population density are also constrained by the availability of adequate dens (Beck-King et al. 1999, Aliaga-Rossel et al. 2008).

The pacarana Dinomys branickii (Peters 1873) is a unique Andean rodent. It is the only extant representative of a once diverse caviomorph family, Dinomyidae, and with males reaching $15 \mathrm{~kg}$, it is the third largest rodent worldwide and the largest in montane humid forest in the Neotropics (White \& Alberico 1992). The species has a patchy distribution in the Andes and western Amazonian foothills from Venezuela to Bolivia, at elevations between 300 and $3400 \mathrm{~m}$. In Colombia, the pacarana occurs in the 3 Andean ranges (Osbahr 1998a). Historically, the pacarana has been considered a rare species (Goeldi 1904, Sanborn 1931, Allen 1942), and as recently as the 1980s was first reported in Venezuela (Boher et al. 1988). This apparent rarity may reflect low population densities or a lack of knowledge of its habits and habitat, as it is an elusive species that inhabits difficult terrain. Pacaranas are gregarious and crepuscular or nocturnal, and spend the day resting in deep, rocky caves near streams (White \& Alberico 1992). Latrine use by all members of a family group is common (Osbahr 2010).

Because of its rarity, patchy distribution, large size, and gregariousness, the pacarana is globally Vulnerable (Tirira et al. 2008), and in Colombia it is threatened by hunting and habitat loss and fragmentation (Alberico et al. 2006). The development of management plans for its conservation is constrained by a lack of precise knowledge of its habitat and resource requirements and responses to forest fragmentation. In this paper, we report on patterns of habitat and space use, population density, diet, and behavior of pacaranas in a rural landscape in the Central Cordillera of the Colombian Andes. We explore factors determining pacarana presence and abundance at 4 spatial scales: landscape, forest patch, foraging area, and den.

\section{MATERIALS AND METHODS}

The study was conducted at elevations of 2000 to $3000 \mathrm{~m}$ on the western slope of the Central Cordillera of the Colombian Andes (Fig. 1; see also Fig. S1 in the Supplement at www.int-res.com/articles/suppl/ n016p273_supp.pdf). To determine the presence of pacaranas at the landscape scale, we conducted surveys in March and June 2000, January to April 2001, and July 2006 to July 2007. We covered an area of approximately $300 \mathrm{~km}^{2}$ through trails that crisscrossed blocks of continuous forest and forest fragments, looking for active dens and other signs of pacarana presence (feces, footprints, or feeding areas). We worked in 3 adjacent, protected areas: Campoalegre Municipal Park (20 000 ha), Ucumarí Regional Park (4000 ha), and Los Nevados National Park (58 000 ha), in the municipalities of Santa Rosa de Cabal and Pereira, Risaralda Department. Campoalegre and Ucumarí are multiple-use management areas that combine conservation and agricultural land uses. Ucumarí is over $80 \%$ forested, whereas in Campoalegre, forest patches are embedded in a productive matrix that includes cattle pastures, commercial tree plantations, and a variety of crops. In Campoalegre, continuous forest exists above $2200 \mathrm{~m}$. Los Nevados is a strictly protected area that includes upper elevation (2600 to $3200 \mathrm{~m}$ ) Andean forest and above $3200 \mathrm{~m}$, a shrub and grassland ecosystem (páramo). Precipitation in this region is bimodal, with rainfall peaks in April to May and October to November. Mean annual precipitation is around $2700 \mathrm{~mm}$. Mean annual temperatures vary from $15^{\circ} \mathrm{C}$ at $2000 \mathrm{~m}$ to $12^{\circ} \mathrm{C}$ at $3000 \mathrm{~m}$. Nighttime temperatures in the páramo may drop to near $0^{\circ} \mathrm{C}$. 

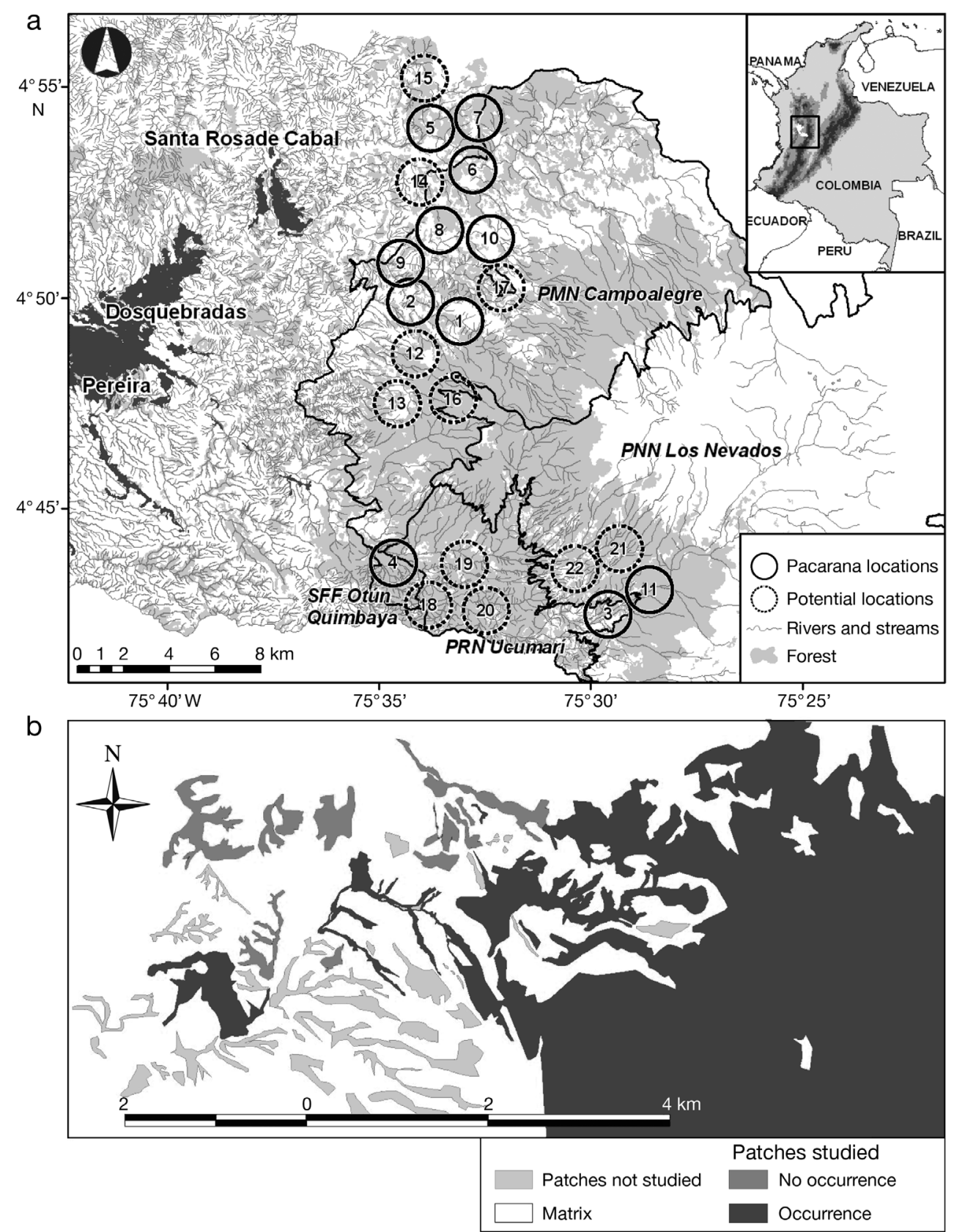

Fig. 1. Study areas in the Central Andes of Colombia. (a) Location of used and randomly selected potential landscapes (3.14 $\mathrm{km}^{2}$ circles) used by, or potentially suitable for use by, the pacarama Dinomys branickii, showing forest areas (gray), urban areas (black) and non-forested areas (white). (b) San Eugenio River watershed (circle no. 1 in Fig. 1a; $75^{\circ} 33^{\prime}$ W, $4^{\circ} 49^{\prime}$ N) showing large block and fragments of forest with confirmed occurence of pacarana (black). Abbreviations correspond to different categories of protected areas. SFF: Sanctuary of Fauna and Flora; PRN: Parque Regional Natural; PNN: Parque Nacional Natural; PMN: Parque Municipal Natural

To characterize the landscape around sites showing signs of pacarana presence, we delimited circles with a radius of $1 \mathrm{~km}$ (area of $3.14 \mathrm{~km}^{2}$ ) on a map. Maps were based on classified Aster and Landsat satellite images from the years 2003 to 2005 . Within each circle, we measured the percent cover of mature and second-growth forest, pasture, timber plantations, and other crops using ArcGIS (ESRI). We characterized landscape heterogeneity with Shannon's index as a measure of diversity of land cover types. To describe physical conditions, we calculated for each circle the mean slope and the density of 
catchment areas with a main stream and a variable number of brooks draining into it, using a digital elevation model with a resolution of $30 \mathrm{~m}$ (see Iverson et al. 2001 for methodological details). To determine whether pacaranas were using sites with particular combinations of landscape variables, we compared sites with pacarana presence to control sites selected by placing random coordinates on the map.

To determine patterns of habitat use at the forest patch, foraging area, and den scales, we conducted more detailed surveys in the San Eugenio River watershed in Campoalegre (Fig. 1b). This study area encompassed 4709 ha, and included a 1643 ha forest block (which was much larger and continuous outside the study area), and forest patches totaling 478 ha in a 2588 ha matrix of pastures, timber plantations, and a variety of small-scale crops. Between July 2005 and June 2006, we visited 17 forest patches, chosen based on elevation (between 2000 and $2300 \mathrm{~m}$ ) and accessibility. In each forest patch, we looked for signs of pacaranas and measured the respective patch area, perimeter, and the shortest edge-to-edge distance to continuous forest (Table 1).

Table 1. Dinomys branickii. Variables used to describe pacarana habitat at 4 spatial scales in the Central Andes of Colombia and comparison of habitat variables measured at sites used by pacaranas and potential sites selected at random. Values are means (SD), p-values are based on Mann-Whitney tests. DBH: diameter at breast height

\begin{tabular}{|c|c|c|c|c|}
\hline Variable & Description & Used & Potential & $U$ (p-value) \\
\hline \multicolumn{5}{|l|}{ Landscape } \\
\hline Forest cover $(\%)$ & Measured within a circle of $1 \mathrm{~km}$ radius & $56.8(25.2)$ & $71.2(24.1)$ & $45(0.3)$ \\
\hline Heterogeneity of land cover types & Shannon diversity index of area of habitat types & $0.8(0.4)$ & $0.6(0.4)$ & $41(0.2)$ \\
\hline Mean slope (\%) & Measured within a circle of $1 \mathrm{~km}$ radius & $18.5(6.1)$ & $19.8(4.0)$ & $51(0.5)$ \\
\hline Stream density $\left(\mathrm{km}^{-2}\right)$ & Number of streams in a drainage divided by area & $1.8(0.4)$ & $1.6(0.4)$ & $39(0.17)$ \\
\hline Sample size & & 11 & 11 & \\
\hline \multicolumn{5}{|l|}{ Forest patch } \\
\hline Patch area (ha) & & $19.6(20.3)$ & $1.8(2.0)$ & $9(0.0)$ \\
\hline Patch perimeter $(\mathrm{m})$ & & $5443(6493.5)$ & 723 (489.9) & $1.8(0.1)$ \\
\hline Distance to continuous forest (m) & Nearest edge-to-edge distance & $981(1031.9)$ & $800.7(399.2)$ & $32(0.8)$ \\
\hline Sample size & & 7 & 10 & \\
\hline \multicolumn{5}{|l|}{ Foraging area } \\
\hline Diversity of vertical strata & $\begin{array}{l}\text { Shannon Index: a } 6 \mathrm{~m} \text { long pole divided into sec- } \\
\text { tions of } 1 \mathrm{~m} \text { was used to measure no. of contacts } \\
\text { with vegetation (no. of contacts with each pole } \\
\text { section = species abundance measurement) }\end{array}$ & $0.7(0.0)$ & $0.7(0.1)$ & $21(0.8)$ \\
\hline Total volume of vegetation $\left(\mathrm{m}^{3}\right)$ & Estimate in mid-level and understory vegetation & $1.3(0.2)$ & $1.3(0.4)$ & $22.5(1)$ \\
\hline Canopy cover $(\%)$ & Measured with a densitometer & $75.7(6.1)$ & $79.5(6.1)$ & $15.5(0.3)$ \\
\hline $\mathrm{DBH}(\mathrm{cm})$ & Mean diameter of trees and shrubs $(>5 \mathrm{~cm})$ & $19.3(5.1)$ & $20.2(8.2)$ & $22(0.95)$ \\
\hline Mid-level vegetation cover (\%) & $\begin{array}{l}\text { Visual estimate of vegetation cover }(\mathrm{DBH}<5 \mathrm{~cm} \\
\text { and height }<5 \mathrm{~m})\end{array}$ & $65(18.7)$ & $78.9(16.6)$ & $8.5(0.6)$ \\
\hline Understory vegetation cover (\%) & Visual estimate of understory vegetation $(<1.5 \mathrm{~m})$ & $71(18.5)$ & $66.1(12.4)$ & $19(0.6)$ \\
\hline Mid-level vegetation height (m) & $\begin{array}{l}\text { Mean height of vegetation with } \mathrm{DBH}<5 \mathrm{~cm} \\
\text { and height }<5 \mathrm{~m}\end{array}$ & $3.1(0.6)$ & $2.92(0.3)$ & $20(0.7)$ \\
\hline Number of plants with $\mathrm{DBH}>5 \mathrm{~cm}$ & & $22.5(12.1)$ & $21.22(12.5)$ & $22(0.9)$ \\
\hline Distance to nearest potential den (m) & & $56(26.9)$ & $142.2(72.9)$ & $8.5(0.1)$ \\
\hline Sample size & & 7 & 8 & \\
\hline \multicolumn{5}{|l|}{ Den } \\
\hline Number of entrances & Single den with multiple entrances & $1.7(0.7)$ & $1.6(2.1)$ & $29(0.13)$ \\
\hline Den area slope $(\%)$ & $\begin{array}{l}\text { Mean slope of } 100 \mathrm{~m}^{2} \text { area around den, measured } \\
\text { with a clinometer }\end{array}$ & $63.3(31.9)$ & $35.4(30.1)$ & $26.5(0.09)$ \\
\hline Diameter of main entrance $(\mathrm{cm})$ & $\begin{array}{l}\text { Diameter of largest entrance in multiple- } \\
\text { entrance dens }\end{array}$ & $45(6.2)$ & $39.5(19.8)$ & $35.5(0.30)$ \\
\hline Depth (m) & $\begin{array}{l}\text { Measured by inserting a stick (see 'Materials } \\
\text { and methods') }\end{array}$ & $6.4(2.1)$ & $2.9(1.6)$ & $10.5(0.003)$ \\
\hline Distance to nearest stream (m) & & $50.1(51.0)$ & $63.6(88.9)$ & $46.5(0.85)$ \\
\hline Exposed rock cover $(\%)$ & $\begin{array}{l}\text { Percent of rock cover in } 100 \mathrm{~m}^{2} \text { area around } \\
\text { den entrance }\end{array}$ & $87.8(10.9)$ & $47.3(29.7)$ & $13(0.006)$ \\
\hline Sample size & & 9 & 11 & \\
\hline
\end{tabular}


We characterized foraging areas and dens within Campoalegre's large block of continuous forest. In each foraging area (identified by signs such as toothmarks in plants; see Fig. S2 in the Supplement at www.int-res.com/articles/suppl/n016p273_supp.pdf), we measured vegetation variables (Table 1 ) in a $25 \times 2$ $\mathrm{m}$ transect and compared them to a control site (potential foraging areas), selected in a random direction within the forest, at least $500 \mathrm{~m}$ from known foraging areas. To test whether dens might be a factor associated with selection of foraging areas, we measured the distance from potential foraging areas to the nearest potential den, and compared it to the distance between used foraging areas and active dens. We identified active dens by the presence of signs such as fresh tracks and hairs. We compared pacarana hair from zoo and museum specimens and from skins of hunted animals, to those of potential sympatric species that also use burrows, such as South American coati Nasua nasua, mountain paca Cuniculus taczanowskii, and Central American agouti Dasyprocta punctata. We measured 6 descriptive variables on dens (Table 1), based on prior knowledge of pacarana ecology and observations of the species' behavior in our study area. We measured den depth by crawling into the cave as far as possible and inserting a long stick. Our measure of depth is a minimum value because sometimes caves had sharp turns that impeded the stick. To avoid disturbing the animals, we took these measurements when the pacaranas were away (i.e. when they were foraging at night or were not using the den). As control sites (potential dens) we used similar rocky caves that showed no signs of having been used by the species.

For each spatial scale, we examined correlations between pairs of variables using Pearson's correlation coefficients, to see which variables needed to be eliminated. We used Mann-Whitney $U$-tests to test for differences between used and potential sites for all variables and spatial scales.

Between July 2005 and June 2006, we made 5 sessions of behavioral observations between 17:00 and 00:00 h in 3 active dens (35 total hours of observation), from hiding places 15 to $20 \mathrm{~m}$ from the den. We waited for the animals' emergence and their return a few hours later. To describe the diet, we collected plants with incisor marks along trails and in feeding areas near dens. To distinguish pacarana marks from those of the sympatric mountain paca, we measured the incisors of 5 paca and 3 pacarana museum specimens from the Universidad del Valle, Cali, Colombia. The incisor marks of pacarana (mean $\pm \mathrm{SE}=15.0 \pm$ $0.7 \mathrm{~mm}$ ) were wider and easily distinguishable from paca marks $($ mean $=8.5 \pm 0.9 \mathrm{~mm})$.
To estimate home ranges and density of pacarana groups in the San Eugenio River watershed, we established 15 transects along mountain ridges and stream margins within continuous forest. The transects varied from 390 to $4000 \mathrm{~m}$, for a total of $23.4 \mathrm{~km}$. To determine pacarana home ranges, we mapped all signs of activity around dens, including trails used by the species and leading from the den to foraging areas and latrines. The longest pacarana trail that we found leading from a den to foraging areas or latrines was $200 \mathrm{~m}$, so we considered signs that were $200 \mathrm{~m}$ or less from other signs as a cluster belonging to a single pacarana group. Data collection for this part of the study was limited to 3 mo (December 2006 to February 2007). Therefore, our home range sizes may be underestimated, because we did not test for an asymptote in home range sizes as more data were added, and we could not detect long excursions. We limited our visits because pacaranas are very sensitive to disturbance and easily abandon dens. We do not know how long pacaranas stay in a particular den in the absence of disturbance, but the animals switch caves spontaneously (López et al. 2000) and apparently have a rotation system, returning to a particular den up to 2 yr later (C. A. Saavedra-Rodríguez pers. obs.). Data were processed in ArcView 3.2 (ESRI), and home ranges were measured using the animal movement extension (Hooge \& Eichenlaub 1997) with the kernel analytical method.

To estimate population density, each transect was sampled twice, in the morning (05:00 to 08:00 h) and evening (18:00 to 21:00 h). We used the fixedwidth transect method, with a predetermined transect width $(W)$ of $10 \mathrm{~m}$ on each side of the trail. Density was calculated as $D=\mathrm{n} / 2 W L$, where $\mathrm{n}$ is the number of sign clusters detected and $L$ is transect length.

\section{RESULTS}

At the landscape scale, we recorded active dens and signs of pacarana activity at 11 sites (Fig. 1). Pacaranas used humid forest habitats near streams in heterogeneous landscapes. Forest cover in landscapes $\left(3.14 \mathrm{~km}^{2}\right.$ circles) varied from 20 to $95 \%$. Areas occupied by pacaranas had slopes between 15 and $30 \%$ and a mean of 2 streams $\mathrm{km}^{-2}$. There were no differences between sites with evidence of pacarana presence and sites selected at random for any of the variables (Table 1, Tables S1 \& S2 in the Supplement at www.int-res.com/articles/suppl/n016p273 _supp.pdf). 
We found evidence of pacarana presence in 7 of the 17 forest patches. There was a correlation between forest patch area and perimeter $(\mathrm{r}=0.76, \mathrm{p}=$ 0.05), so we eliminated perimeter from the analysis. Forest patches with pacarana presence were significantly larger than patches with no evidence of current pacarana presence (Table 1).

Within continuous forest, we located 25 areas with foraging signs, but only 7 were associated with active dens and were used for analysis (we did not find dens associated with the other 18 areas, but some may have been in rocky slopes inaccessible to us). None of the vegetation variables showed significant differences between used and potential foraging areas, but there was a marginally significant difference in the distance between foraging areas and dens, with used sites closer to active dens than potential sites (Table 1).

Den characteristics were examined in 9 used and 11 potential caves. There were significant differences between used and potential dens in den depth and rock cover (Table 1). Used dens were deeper and had a higher percent rock cover than potential caves. There was a statistical tendency for used dens to have a higher slope than potential caves (Table 1). There were no differences between used and potential caves in entrance diameter or distance to stream (Table 1).

Based on the presence of dens, footprints, foraging areas, and latrines, we obtained home range maps for 4 pacarana groups. Mean home range size was 2.45 ha $(\mathrm{SD}=$ $0.62,95 \%$ CI $=2.425-2.470$ ha; Figs. S3 \& S4, Table S3 in the Supplement at www.int-res.com/articles/ suppl/n016p273_supp.pdf). Pacarana groups used burrows that consisted of 1 to 8 caves that were 2 to $100 \mathrm{~m}$ apart, each cave with a single or multiple entrances. Latrines and foraging areas were located 26 to 60 $\mathrm{m}$ and 10 to $150 \mathrm{~m}$ away from active burrows, respectively. Burrows, latrines, and foraging areas were connected by a system of paths that tunneled through thick understory vegetation.

Observations at active dens $(n=3)$ revealed 2 groups of 4 and 1 group of 5 individuals. Groups were composed of 2 adults (presumably a male and a female) and 2 or 3 juveniles. The groups initiated activities at dusk (18:30 h), when the larger individual (presumably a male) partially emerged from the cave emitting soft grunts and clacking its teeth, and then backed into the cave. Two minutes later it re-emerged, followed by the rest of the group, and followed a trail to a feeding area. Individuals came back into the den independently between 22:00 and 23:00 h. Some activity could be heard within the cave for about $5 \mathrm{~min}$ after the last animal entered.

During transect sampling, we counted 3 individuals (1 adult and 2 juveniles), 17 dens, 3 latrines, and 26 sign clusters consisting of foraging signs or footprints. Signs of pacarana presence were detected in 8 of the 15 transects. In many cases, we found signs but no active dens nearby, so we calculated 2 population densities: using only sign clusters, we estimated a density of 9.9 groups $\mathrm{km}^{-2}(\mathrm{SD}=14.2,95 \% \mathrm{CI}=$ 9.62-10.06); using only dens, our density estimate was 5.5 groups $\mathrm{km}^{-2}$ (SD $\left.=7.2,95 \% \mathrm{CI}=5.35-5.58\right)$.

In foraging areas we obtained evidence of 18 plant species eaten by pacaranas (Table 2). The animals fed on diverse plant parts including foliage, fruits, and succulent stems and rhizomes from ferns, herbs, shrubs, and trees. Fruits eaten included the fallen, soft fruits of fig trees (Ficus spp.), hard fruits such as acorns of Quercus humboldtii and nuts of Juglans neotropica, as well as the whole infructescenses of herbaceous Anthurium sp.

Table 2. Dinomys branickii. Plant species and parts eaten by pacaranas in the Andes of Colombia, determined in this study and recorded from other Colombian localities (Osbahr 1998 a,b, 1999)

\begin{tabular}{|c|c|c|c|c|}
\hline Family & Species & Plant parts & Present study & Osbahr \\
\hline Apiaceae & Myrrhidendron pennellii & Roots & $x$ & \\
\hline Araceae & Anthurium sp. & Leaf, stem, fruit & $x$ & $x$ \\
\hline \multirow[t]{2}{*}{ Arecaceae } & Geonoma sp. & Young leaf & $x$ & \\
\hline & Wettinia kalbreyeri & Young leaf & $x$ & \\
\hline Asteraceae & Bidens sp. & Leaf, stem & & $x$ \\
\hline Blechnaceae & Blechnum sp. & Leaf & $x$ & $x$ \\
\hline Boraginaceae & Cordia sp. & Leaf, stem & & $x$ \\
\hline \multirow[t]{2}{*}{ Commelinaceae } & Unidentified & Leaf, stem & & $x$ \\
\hline & Ageratum sp. & Leaf, stem & & $x$ \\
\hline Cyclanthaceae & Cyclanthus sp. & Leaf, stem & $x$ & $x$ \\
\hline Dryopteridaceae & Dryopteris sp. & Leaf, stem & $x$ & $x$ \\
\hline Gunneraceae & Gunnera manicata & Stem, rhizome & $x$ & \\
\hline Fagaceae & Quercus humboldti & Acorn & & $x$ \\
\hline Heliconiaceae & Heliconia sp. & Leaf, stem & $x$ & $x$ \\
\hline Juglandaceae & Juglans neotropica & Nut & $x$ & \\
\hline Moracea & Ficus gigantocise & Fruit & $x$ & \\
\hline \multirow[t]{4}{*}{ Poaceae } & Arundo sp. & Leaf, stem & & $x$ \\
\hline & Chusquea sp. 1 & Leaf, stem & $x$ & \\
\hline & Chusquea sp. 2 & Leaf, stem & $x$ & \\
\hline & Guadua sp. & Leaf, stem & & $x$ \\
\hline \multirow[t]{2}{*}{ Solanaceae } & Solanum sp. & Leaf, root & $x$ & \\
\hline & Unidentified (3 spp.) & Leaf, stem & $x$ & \\
\hline
\end{tabular}




\section{DISCUSSION}

In the Central Andes of Colombia, pacaranas used landscape units $\left(3.14 \mathrm{~km}^{2}\right.$ circles) with as little as $20 \%$ forest cover. At a local scale, pacaranas usually occupied larger forest patches (mean = 12 ha), but they were present in patches as small as 5 ha, independently of their distance to continuous forest. It is important to note, however, that there is a large and continuous block of forest at upper elevations (2200 to $3200 \mathrm{~m}$ ), which may be acting as a population source. Pacaranas in fragments are probably more vulnerable to hunting and may constitute population sinks.

Pacaranas used a wide variety of plant food sources (Table 2), including species from mature and secondgrowth forest. Some of these plants (e.g. Gunnera manicata) are common in humid, disturbed areas, such as steep slopes near streams where small landslides frequently occur. Rocky outcrops with caves are also more common near streams, and these rocky areas are frequently exposed as a result of landslides. Therefore, the association of pacaranas with streams may actually be dictated by the presence of burrows and feeding areas rather than by the stream itself.

There are no published estimates of pacarana home ranges or population densities. For comparative purposes, the most ecologically similar species are agoutis and pacas, but these rodents are solitary and have more frugivorous diets. Amazonian redrumped agoutis Dasyprocta leporina (body mass of 3 to $6 \mathrm{~kg}$ ) have home ranges of 2.3 to 4.5 ha and densities that vary between 9 and 61 ind. $\mathrm{km}^{-2}$ (Silvius \& Fragoso 2003, Jorge \& Peres 2005). The smaller (up to $3 \mathrm{~kg}$ ) Central American agouti uses home ranges of up to $2.5 \mathrm{ha}$, and may reach densities of $100 \mathrm{ind} . \mathrm{km}^{-2}$ (Aliaga-Rossel et al. 2008). The paca Cuniculus paca is larger $(12 \mathrm{~kg})$ but also has home ranges of 2 to 3 ha and may reach densities of 93 ind. $\mathrm{km}^{-2}$ (Beck-King et al. 1999). All 3 species exhibit considerable geographic variation in density, which may be as low as 3 to 5 ind. $\mathrm{km}^{-2}$ for both Central American agouti and paca, depending on local ecological conditions such as habitat productivity and predator abundance (Swihart et al. 1988, Beck-King et al. 1999, AliagaRossel et al. 2008). Considering the higher biomass represented by pacarana groups, their home ranges are relatively small ( $<3 \mathrm{ha})$, but their population densities (5.5 groups $\mathrm{km}^{-2}$ as a low estimate) are within the ranges reported for agoutis and pacas.

The need to return to a burrow probably limits pacarana home ranges, as occurs with central place foragers (Swihart et al. 1988). This slow-walking ani- mal, with an average speed of $1.04 \mathrm{~km} \mathrm{~h}^{-1}$ (Osbahr \& Azumendi 2010), apparently does not move long distances during its nocturnal activity. During foraging, the species exhibits exploratory behavior of the food patches and manipulates food with the forepaws, so it is expected that these animals do not invest too much time searching for food but will prefer foodstuffs with high fiber and protein content (Osbahr \& Restrepo-Mejia 2001). Because of their highly herbivorous and varied diet, pacaranas may find enough food resources in a relatively small area, but presumably food in the form of vegetative plant parts will eventually be depleted (particularly slow-growing succulent stems and rhizomes) and pacaranas will have to move to a different area. This species does not make nests and frequently changes its burrows and latrine sites (López et al. 2000, Osbahr 2010). Therefore, burrow availability is probably a major factor limiting pacarana distribution and abundance.

Multi-scale studies are important for identifying critical factors limiting populations of threatened animals (Fig. 2) and developing effective conservation strategies (Boyd et al. 2008). Our surveys at large spatial scales suggested that pacaranas can persist in forest fragments, but are usually absent from the smaller patches. At small scales, however, we identified caves as the critical resource. Caves were deep ( $>4 \mathrm{~m}$ ) and were located in areas with $>60 \%$ slope and $>40 \%$ rock cover. Pacaranas used small forest fragments that had caves with these characteristics. These small fragments were frequently strips of veg-

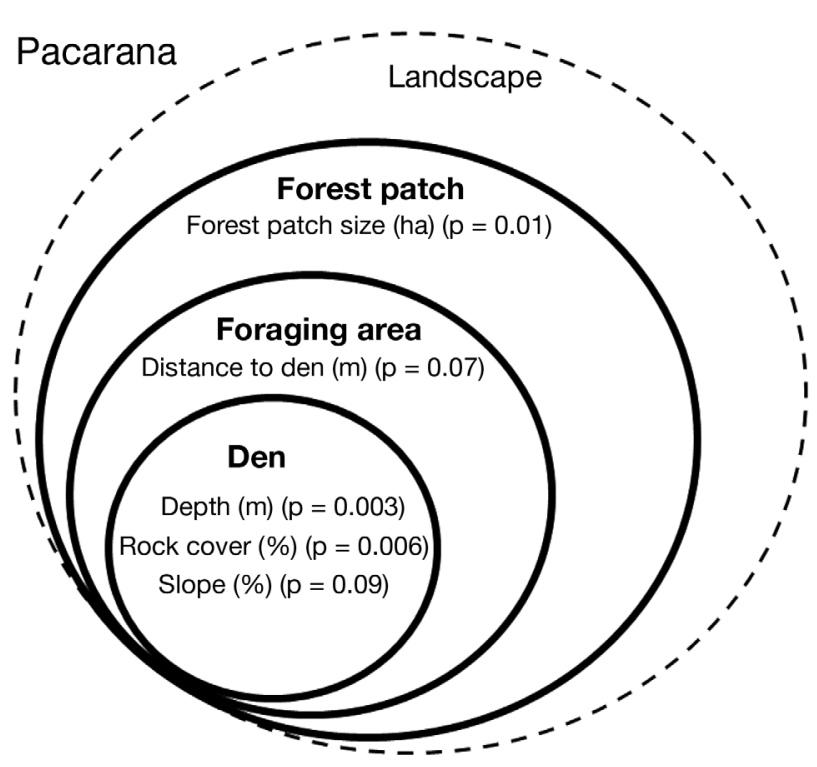

Fig. 2. Dinomys branickii. Conceptual diagram of factors determining pacarana habitat use at 4 spatial scales in the Central Andes of Colombia (after Bunnell \& Huggard 1999) 
etation along steep-sided streams. Therefore, the conservation of pacarana populations in rural landscapes may be helped by protecting forest patches with adequate burrows. Although the convenience of investing in wildlife corridors has been questioned, protection of strips of forest along streams would also favor connectivity among pacarana subpopulations. The maintenance of riparian strips in agricultural landscapes helps to reduce the impacts of human practices and provides important wildlife habitat (Taylor et al. 1993, MacDonald 2003). Under these circumstances, hunting is likely a more serious threat than habitat availability.

The pacarana is a relict rodent taxon in a monotypic family of high conservation priority (Amori \& Gippoliti 2003) that has unique behavioral and morphological adaptations (Osbahr et al. 2009). Extinction risk factors related to phylogenetic uniqueness (Russell et al. 1998, Purvis et al. 2000) and relatively low population density are exacerbated by hunting and habitat loss in a region of high human population densities. Although pacarana populations may exist in several Colombian national parks, they are vulnerable to poaching and at risk of being isolated. Rural landscapes may contribute to the persistence of pacarana populations by providing habitat and connectivity, through the protection of networks of forest patches and riparian strips of vegetation in private lands (Osbahr 1998b), if illegal hunting is controlled.

Acknowledgements. We thank C. Murcia, G. Corredor, V. Rojas-Díaz, J. Velasco, L. Valenzuela, D. Osorio-Dominguez, W. Cardona, C. Gómez-Posada, C. Valderrama, J. MartinezGómez, P. Franco, and C. Ríos-Franco for their useful comments on parts or all of this work. Funding was provided by the John D. and Catherine T. McArthur Foundation, Idea Wild, and Universidad del Valle. CARDER (the regional environmental authority of the Risaralda Department) granted the research permit. E. Nadachowski and M.Y. Valencia were key supporters of the work. Smurfit Kappa Cartón de Colombia allowed access to forest patches in their land. This work is part of C.A.S.R.'s M.Sc. thesis at the Universidad del Valle, and thanks are extended to his graduate committee, A. Giraldo, H. Álvarez-López, and J. Pérez for their advice. C.A.S.R. was supported by a Colciencias scholarship during the writing of this paper.

\section{LITERATURE CITED}

Alberico M, Osbahr K, González-Hernández A (2006) Guagua loba Dinomys branickii. In: Rodríguez-Mahecha JV, Alberico M, Trujillo F, Jorgenson J (eds) Libro rojo de mamíferos de Colombia. Serie Libros Rojos de Especies Amenazadas de Colombia. Conservación Internacional Colombia \& Ministerio de Ambiente, Vivienda y Desarrollo Territorial, Bogotá, p 294-299
Aliaga-Rossel E, Kays RW, Fragoso JMV (2008) Home-range use by the Central American agouti (Dasyprocta punctata) on Barro Colorado Island, Panama. J Trop Ecol 24: 367-374

Allen GM (1942) Extinct and vanishing mammals of the Western Hemisphere with the marine species of all oceans. Special Publication no. 11. American Committee for International Wildlife Protection. Intelligencer Printing Co., Lancaster, PA

Amori G, Gippoliti S (2003) A higher-taxon approach to rodent conservation priorities for the 21st century. Anim Biodivers Conserv 26:1-18

Beck-King H, von Helversen O, Beck-King R (1999) Home range, population density, and food resources of Agouti paca (Rodentia: Agoutidae) in Costa Rica: a study using alternative methods. Biotropica 31:675-685

Boher S, Naveua J, Escobar L (1988) First record of Dinomys branickii for Venezuela. J Mammal 69:433

Boyd C, Brooks TM, Butchart SHM, Edgar GJ and others (2008) Spatial scale and the conservation of threatened species. Conserv Lett 1:37-43

Bunnell FL, Huggard DJ (1999) Biodiversity across spatial and temporal scales: problems and opportunities. For Ecol Manag 115:113-126

Ciarniello LM, Boyce MS, Seip DR, Heard DC (2007) Grizzly bear habitat selection is scale dependent. Ecol Appl 17: 1424-1440

> Coppeto SA, Kelt DA, Van Vuren DH, Wilson JA, Bigelow S (2006) Habitat associations of small mammals at two spatial scales in the northern Sierra Nevada. J Mammal 87: 402-413

Goeldi E (1904) On the rare rodent Dinomys branickii Peters. Proc Zool Soc Lond 2:158-162

Haythornthwaite C, Dickman R (2006) Distribution, abundance and individual strategies: a multi-scale analysis of dasyurid marsupials in arid central Australia. Ecography 29:285-300

Hooge PN, Eichenlaub B (1997) Animal movement extension to ArcView version 1.1. US Geological Survey, Anchorage, AK

Iverson LR, Szafoni DL, Baum SE, Cook EA (2001) A riparian wildlife habitat evaluation scheme developed using GIS. Environ Manag 28:639-654

Johnson DH (1980) The comparison of usage and availability measurements for evaluating resource preference. Ecology 61:65-71

> Johnson CJ, Seip DR, Boyce MS (2004) A quantitative approach to conservation planning: using resource selection functions to map the distribution of mountain caribou at multiple spatial scales. J Appl Ecol 41:238-251

- Jorge ML, Peres C (2005) Population density and home range size of red-rumped agoutis (Dasyprocta leporina) within and outside a natural Brazil nut stand in southeastern Amazonia. Biotropica 37:317-321

López L, López I, Mora J, Osbahr K (2000) Estudio preliminar del comportamiento de Dinomys branickii (Peters 1873) en cautiverio. Rev UDCA Actual Divulg Cient 3: 28-35

Luck GW (2002) The habitat requirements of the rufous treecreeper (Climacteris rufa). 1. Preferential habitat use demonstrated at multiple spatial scales. Biol Conserv 105:383-394

MacDonald MA (2003) The role of corridors in biodiversity conservation in production forest landscapes: a literature review. Tasforests 14:41-52 
Osbahr K (1998a) Contribución al conocimiento de la Guagua Loba (Dinomys branickii). In: Chávez ME, Arango N (eds) Informe nacional sobre el estado de la biodiversidad 1997, Tomo III. Instituto de Investigación de Recursos Biológicos Alexander von Humboldt, Bogotá, p 83-87

Osbhar K (1998b) Guía para la conservación de la guagua loba (Dinomys branickii). Secretaría Ejecutiva Convenio Andrés Bello (SECAB), Santafé de Bogotá

Osbahr K (1999) Identificación de plantas consumidas por Agouti taczanowskii y Dinomys branickii a partir de fragmentos vegetales recuperados de heces. Rev UDCA Actual Divulg Cient 2:42-49

Osbahr K (2010) Evaluación de la tasa de defecación y del uso de letrinas en la guagua loba (Dinomys branickii Rodentia Dinomyidae). Rev UDCA Actual Divulg Cient 13:57-67

Osbahr K, Azumendi JL (2010) Comparación de la cinemática de los miembros de dos especies de roedores histricognatos (Cuniculus taczanowskii y Dinomys branickii). Rev UDCA Actual Divulg Cient 12:39-51

Osbahr K, Restrepo-Mejia D (2001) Determinación de calcio, hierro, proteina y otros requerimientos de nutrientes de Dinomys branickii (Peters 1873). Rev UDCA Actual Divulg Cient 4:44-55

Osbahr K, Acevedo P, Villareal A, Espinosa D (2009) Comparación de la estructura y de la función de los miembros anterior y posterior de Cuniculus taczanowskii y

Editorial responsibility: Brendan Godley, University of Exeter, Cornwall Campus, UK
Dinomys branickii. Rev UDCA Actual Divulg Cient 10: $37-49$

> Purvis A, Agapow PM, Gittleman JL, Mace GM (2000) Nonrandom extinction and the loss of evolutionary history. Science 288:328-330

Russell GJ, Brooks TM, McKinney MM, Anderson CG (1998) Present and future taxonomic selectivity in bird and mammal extinctions. Conserv Biol 12:1365-1376

> Saab VA (1999) Importance of spatial scale to habitat use by breeding birds in riparian forests: a hierarchical analysis. Ecol Appl 9:135-151

Sanborn C (1931) Notes on Dinomys. Field Mus Nat Hist Zool Ser 18:149-155

Silvius K, Fragoso JV (2003) Red-rumped agouti (Dasyprocta leporina) home-range use in Amazonian forest: implications for the aggregated distribution of forest trees. Biotropica 35:74-83

Swihart RK, Slade NA, Bergstrom BJ (1988) Relating body size to the rate of home range use in mammals. Ecology 69:393-399

Taylor PD, Fahrig L, Henein K, Merriam G (1993) Connectivity is a vital element of landscape structure. Oikos 68: 571-573

Tirira D, Vargas J, Dunnum J (2008) Dinomys branickii. In: 2008 IUCN Red List of Threatened Species. Available at www.iucnredlist.org (accessed on 11 October 2010)

> White TG, Alberico M (1992) Dinomys branickii. Mamm Species 410:1-5

Submitted: October 12, 2010; Accepted: October 10, 2011

Proofs received from author(s): February 28, 2012 